\title{
Service Quality From Islamic Perspective and Its Connection With Customer Satisfaction With Public Transportation Sector In Terengganu
}

\author{
Noor Malinjasari Binti Ali \\ Faculty of Business \& Management \\ Universiti Teknologi MARA \\ Terengganu, Malaysia \\ noorm726@tganu.uitm.edu.my \\ Kardina Kamaruddin \\ Faculty of Business \& Management \\ Universiti Teknologi MARA \\ Kedah, Malaysia \\ kardina@kedah.uitm.edu.my
}

\author{
Siti Fatimah Mardiah Hamzah \\ Faculty of Business \& Management \\ Universiti Teknologi MARA \\ Terengganu, Malaysia \\ sfatimah@tganu.uitm.edu.my \\ Hasmida Mohd Noor \\ Faculty of Business \& Management \\ Universiti Teknologi MARA \\ Terengganu, Malaysia \\ hasmidam@tganu.uitm.edu.my
}

\author{
Rahayu Izwani Borhanuddin \\ Faculty of Accountancy \\ Universiti Teknologi MARA \\ Johor, Malaysia \\ rahay823@johor.uitm.edu.my
}

\begin{abstract}
Customer satisfaction has been well documented and discussed on its connection to organizational performance. Although many researchers have studied both issues, there are still lack of studies that focus on customer satisfaction and service quality from the Islamic perspective and in connection with public transportation services. Therefore, this was a preliminary study to examine customer satisfaction from the Islamic perspective in public transportation services. SERVQUAL was used to measure service quality. About 200 survey questionnaires had been distributed using convenience sampling in Terengganu. Data were analyzed using i) method of importance, ii) performance of quality analysis, and analysis gap between experiences and expectations. From the analyses, respondents had given a variety of responses on the levels of customer satisfaction. This study had emphasized on customer satisfaction in public services and the importance of implementing continuous improvements on service quality
\end{abstract}

Keywords - customer satisfaction, service quality, tangible, responsiveness, reliability, assurance and empathy, public transport, Islamic perspective

\section{INTRODUCTION}

There have been many complaints on the qualities of public transportation in Malaysia [1]. Since the 1990s, among the grievances that had been mentioned were punctuality of services, poor conditions of the vehicles, drivers' attitudes and the transportation providers' accountability towards customer's safety [2]. Although, many complaints about public transportation services had been broadcasted, out of 362 cases or complaints that had been received, only 325 complaints or 89.8 percent were solved in 2010 and remaining 37 cases under investigation [3]. The issues on poor public transport services in Terengganu had been studied in 2008 and found that the level of customer satisfaction on public busses in Terengganu was low, only at about 38.69 percent [2]. In Terengganu, public transportation encompasses express buses, stage buses, school buses, rental cars, and freight transportation providers. Although there were stated the services were not comprehensively covered and operations were very limited in the remote areas in the state. Also, the public transportation terminal station facilities in all districts had not been able to support and strengthen the public transport services nor can it support the tourism activities [4]. This is supported by Ir Rosli Othman, the Chairman of Public Work and Public Transport, Terengganu State, that public transportation services in Terengganu were poor [5]. Therefore, this study was conducted to measure the level of customer satisfaction to public transportation services in Terengganu particularly in Dungun area using quality analysis and SERVQUAL. Secondly, the study had analyzed the gap on public transportation services using the relationship between customer satisfaction (perception) and the importance of service quality elements (expectations) using SERVQUAL techniques. The researchers also studied the variables that had significant impact on public transportation users in Dungun Terengganu. 


\section{LITERATURE REVIEW}

\section{A. Customer Satisfaction}

Customer satisfaction had always been measured by how the customer's perceived and viewed the good and services being offered by an organization [6] [7] [8]. In business, customer satisfaction was defined as how the products and services can attract customers [9]. There are many studies on customer satisfaction including the benefits to the organization if they could satisfy their customers; it can assure the success and longevity of the business [6] [7] [8] Companies that were able to satisfy the customers' needs would have higher economic returns [9]. Most of the researchers defined customer satisfaction as an individual feeling whether they feel good or not when they compare between the performance that they experienced and their expectations [8] [7] [6]. In general, customer satisfaction had been linked to the five attributes in service quality [6] [7] [8] [9].

\section{B. Service Quality in Islamic Perspective}

Individual and organization defined quality according to their classification, characteristics, opinions and expectations based on their measurement [6] [7] [8] In the Islamic context, quality was being identified through words like hasanat, toyyibat, al-khair, al-haq, and al-ihsan as mentioned in few Hadith and in the Holy Quran. Service quality can be delineated as services that were suitable and effective in achieving the goals and efficient from the technical and economic aspects [2]. Service quality was also defined as customer assessment of organizational excellence as a whole [6] [7] [8] [9] [10]. However, service quality was heavily dominated by the work of Parasuraman et al [11] that demarcated the concept through five important attributes or elements; i) tangibles, ii) assurance, iii)responsiveness, iv)reliability and v) empathy. These elements were translated to an instrument known as SERVQUAL which has been modified various times to increase accuracy in data analysis.

Firstly, The tangible aspect of SERVQUAL referred to physical facilities like ensuring the public transportation to be in its best conditions and offered the finest services to its customers. This statement was in line with the versus in alQuran that said Allah SWT had created humans in the best of forms (al-Quran; Tiin: 4)[12]. Therefore, humans are responsible for preserving what is given to him because he was given the most excellent in all aspects of his life by the Creator. Thus, it was only fair that as a person we only give the best services to the people around us. The golden rule in Islam stated that "Do unto all men as you would wish to have done unto you; and reject for others what you would reject for yourselves." (Abu Dawud) [13]. Secondly, reliability was defined as the ability to perform the services offered or promised accurately. It means that the staff on duty had to honor the promises by giving excellent services as being stated in customer charter. This includes preparing the bus schedule to facilitate the customers, in terms of their travelling comfort, safety, trust on the services provided, customer's confidentiality, flexibility of travelling to accommodate praying time for the Muslims and in addition, drivers' qualification and work etiquette [6] [7] [8] [9]. This is in line with al-Quran versus that stressing out on reliable workers i.e. workers that had the qualifications, skills, expertise, knowledge and can be trusted (al-Quran; Qashash:36) [12].

Thirdly, assurance meant that the organization could assure that the staff on duty is knowledgeable, gracious, and able to convince customers and create a sense of security while using their services. To achieve assurance, employees need to have good communication skills, credibility, efficiency, well-informed and courteous. Fourthly, responsive meant that the staff are ready to offer prompt services to needed customers, follow flexible schedules, entertain customers with fairness, and efficient in offering the services according to customers wants and needs [6] [7] [8] [9]. Lastly, empathy indicates that the staff on duty could understand how the customer feels by offering services that could satisfy the customers. This elements measure how staff can extent the services by prioritizes customers and understands the needs of customers who deal with them, have sympathies, and always respect and gives consideration to problems that being submitted [6] [7] [8] [9].

SERVQUAL through the Islamic perspectives focuses on the how the service providers are accountable for their contracts with their customers through their client charter. These contracts are words that bound to them to their patrons as promises to give the best services and serve the customers as it is their rights. In the Quran, contravention ones promise is deemed erroneous. The Holy Qur'an [12] denounces the breaking of promise in the following verse:

"Yea, whoever fulfills his promise and guards (against evil) - then surely Allah loves those who guard (against evil). (As for) those who take a small price for the covenant of Allah and their own oaths - surely they shall have no portion in the hereafter, and Allah will not speak to them, nor will He look upon them on the Day of Resurrection nor will He purify them, and they shall have a painful chastisement." (Surah Ali'Imrān 3:76-77)

Similarly we find another verse of the same connotation:

"Surely the vilest of animals in Allah's sight are those who disbelieve; then they would not believe.Those with whom you agree, then they break their agreement every time and they do not guard (against punishment)." (Surah al-Anfāl 8:55-56)

In various places in the Holy Qur'an, fulfilling a promise has been made obligatory and highly emphasized.

For example,

“..and fulfill the promise, surely (every) promise shall be questioned about." (Surah al- 'Isrā', 17:34)

Also,

"O you who believe! Fulfill the obligations." (Surah alMā'ida 5:1)

Similarly, in Surah al-Baqarah the verse says,

"... and the performers of their promise when they make a promise..." (Surah al-Baqarah 2:177)

We also find the following verse: 
"O you who believe! Why do you say that which you do not do? It is most hateful to Allah that you should say that which you do not do." (Surah as-Saff 61:2-3),

\section{Customer Satisfaction and Service Quality in Public Transport Sector}

The relationship between customer satisfaction and service quality had been extensively studied [14]. The empirical study found out there is a positive relationship between customer satisfaction and service quality [15]. Companies that had good service quality can satisfy their customers [16] [17]. Most of the research that linked between customer satisfaction and service quality using SERVQUAL were done in banking sector healthcare industries, retailing, education, fast food restaurant and pharmacy [18] [19]. Even though there was critique on SERVQUAL, many researchers believed the reliability of the instrument [6] [7] [8] [9] [10] [14] [15] [16] [18].

Service quality on public transportation in Malaysia had always being associated with lower customer satisfaction with the public transportation usage in Malaysia was around 20.0 percent as stated by Datuk Dr. J Loga Bala Mohan, Deputy Minister of Ministry of Federal Territory [1]. The low utilization of public transportation were because the buses always arrive late, untidy, unattractive terminal, customers have to wait longer than expected, the bus drivers using complex transit route, not reliable, not customers oriented, drivers that drove exceeded the speed limit, not given priority to customer safety and workers that lacking of empathy [2] [8] [20] [20] [22].

The performance of transport operators or service providers can influence the level of customer satisfaction [23] [24]. An efficient transportation services would make customers satisfied with the money that they had invested in getting the service. The perception and their level of satisfaction would also be influenced by their emotional reactions based on their experiences when they were using the transportation services. If the transportation service could satisfy them, they would use it in the future and if the transport service could not satisfy them, they would avoid using the same services in the future. [8] [22] [25] [26]. The public transportation services that can apply the Islamic values such as punctuality, trustworthy, reliability, empathetic and excellent services through the staff at the counter tickets, the terminal facilities, drivers and unit of carriage conditions could give satisfaction to the customers[2].

\section{METHODOLOGY}

This survey was conducted in Dungun, Terengganu to survey and measure the customer satisfaction on service quality of public transportation sector. The questionnaires were distributed to people living and working in this area. This study concentrated on five elements or five important dimensions in SERVQUAL; tangible, assurance, responsiveness, reliability and empathy. Customer satisfaction and the importance of the elements are being measured using Likert scale from 1 to 7 . For customer satisfaction aspect, scale 7 shows that the customers were really satisfied whereas scale 1 shows that the customers were not satisfied with the services. To show the importance of the elements in the service quality, scale 1 refers to: are not so important whereas scale 7 shows that the elements are so very important. The definition and terminologies of importance and satisfaction had been informed to respondents to facilitate the respondents in answering the questionnaire. The interview method had also been conducted randomly to ensure the respondents understand what was being written in the survey questionnaires. The survey questionnaires using convenience sampling and about 200 set had been distributed. This study analyzed data by replicating a study being done by Wan Rosmanira [27]. The service quality for each element that had been measured was the ratio between perception and expectation. This ratio was known as the quality value of $\mathrm{Q}$ and is expressed in the formula as in Table 1 below:

TABLE 1: INTERPRETATION TOWARDS SERVICE QUALITY VALUE

\begin{tabular}{|l|l|}
\hline Quality value $(\mathrm{Q})$ & Perception \\
\hline $\mathrm{Q}>1.00$ & satisfied \\
\hline $\mathrm{Q}=1.00$ & minimum expectation \\
\hline $\mathrm{Q}<1.00$ & not satisfied \\
\hline \multicolumn{2}{|l|}{ Quality value $(\mathrm{Q})=$ actual performance $($ satisfaction/perception)/importance expectation } \\
\hline
\end{tabular}

The level of customer satisfaction also could be conducted through analysis gap. It could be measured based on the score differences between satisfaction and importance. The positive gap value showed that the customers were satisfied or vice versa. The Cronbach Alpha had been used to 16 early samples using simple random sampling in the pilot study. Based on the value $(0.6-0.9)$, the scale used in the survey was suitable to produce the valid and reliable answers.

\section{DATA FINDINGS}

\section{A. Respondent Profile}

The average of 80 percent response rate was collected in the study with 200 survey questionnaire had been distributed, and 160 set had been returned with complete answer. Respondents were mostly in the age bracket of 19-21 years old (80.63 percent). The rest were below 18 years old ( 23.5 percent) and between $22-25$ years old (6.87 percent). No respondents age 26 years old and above as the respondents with the age bracket did not fill the survey completely. 52.5 percent respondents were males whereas the rest were females. For route, the highest route taken is the route Kuala Terengganu/Dungun to Shah Alam/Kuala Lumpur about 27.5 percent whereas the route to Dungun-Kuantan/Pahang and Dungun-Kelantan about 17.5 percent each. The rest are route to Kuala Terengganu/Dungun - Kedah (6.88 percent), Kuala Terengganu/Dungun-Johor Bahru/Segamat/Batu Pahat (3.12 percent), Kuala Terengganu/Dungun - Pulau Pinang (5.0 percent), Kuala Terengganu/Dungun - Perak (7.5 percent). The other miscellaneous routes were the route around Kuala Terengganu including the travel to Besut, Kemaman, Kuala Terengganu, Bukit Besi and around Dungun. 


\section{B. Service Quality}

Table 2 showed the quality according to five dimensions that had been set earlier. In general, all the five dimension of service quality showed the level satisfaction is low, $\mathrm{Q}<1.00$. This shows that the entire dimension is not meeting the minimum expectations of the customers. The lower quality (0.74) was on the buses which were not punctual (not as schedule) whereas the higher quality $(0.88)$ were buses that have attractive visual as shown in Table 2. This proved that the buses were not reliable, and the schedule of the buses was not well planned. However, the unexpected factors like congestion and accident need to be considered as why the buses were not reliable. For service dimensions, the score for empathy and responsiveness were lower with 0.78 . Therefore, empathy and responsiveness dimensions needed to be given more consideration by transportation providers when preparing for their services. The mean for customer satisfaction was 0.71 and could be translated as the public transport service was not meeting the minimum expectation and there was room for improvement. However, since the value was approaching to value 1 , it shows that the public transportation services can be improved by improving all the elements that had lower scores. Consequently, customer satisfaction can be achieved. The important variables in this research were reliability dimension with the highest mean score of 5.85 as shown in Table 2 below.

TABLE 2: QUALITY ANALYSIS ON EACH ELEMENTS AND SERVICE DIMENSION

\begin{tabular}{|c|c|c|c|c|c|}
\hline $\begin{array}{l}\text { Di } \\
\text { me } \\
\text { nsi } \\
\text { on }\end{array}$ & $\begin{array}{c}\text { Types of } \\
\text { Service } \\
\text { Dimensio } \\
\text { ns } \\
\end{array}$ & $\begin{array}{c}\text { Elements of Service } \\
\text { Dimension }\end{array}$ & $\begin{array}{c}\text { Mean } \\
\text { Satisfac } \\
\text {-tion }\end{array}$ & $\begin{array}{l}\text { Mean } \\
\text { Import } \\
\text {-ance }\end{array}$ & $\begin{array}{c}\text { Quali } \\
\text { ty } \\
\text { (Q) }\end{array}$ \\
\hline \multirow[t]{10}{*}{1} & \multirow[t]{10}{*}{ Reliability } & $\begin{array}{l}\text { a. Bus arrives on } \\
\text { time }\end{array}$ & 4.16 & 5.63 & 0.74 \\
\hline & & $\begin{array}{l}\text { b. Bus departs from } \\
\text { terminal according } \\
\text { to the schedule }\end{array}$ & 4.30 & 5.53 & 0.78 \\
\hline & & $\begin{array}{l}\text { c. The bus services are } \\
\text { reliable }\end{array}$ & 4.98 & 5.78 & 0.86 \\
\hline & & $\begin{array}{l}\text { d. The passenger } \\
\text { arrives safely at the } \\
\text { destination }\end{array}$ & 5.36 & 6.20 & 0.86 \\
\hline & & $\begin{array}{l}\text { e. The workers are } \\
\text { trustworthy }\end{array}$ & 5.08 & 5.98 & 0.85 \\
\hline & & $\begin{array}{l}\text { f. The workers can be } \\
\text { trusted with the } \\
\text { customer's } \\
\text { confidentiality }\end{array}$ & 4.71 & 5.76 & 0.82 \\
\hline & & $\begin{array}{lr}\text { g. The } & \text { transport } \\
\text { provider } & \text { provides } \\
\text { the } & \text { conducive } \\
\text { services } & \\
\end{array}$ & 4.92 & 6.02 & 0.82 \\
\hline & & $\begin{array}{l}\text { h. The public transport } \\
\text { provider honors the } \\
\text { promise } \\
\text { customers }\end{array}$ & 4.72 & 5.76 & 0.82 \\
\hline & & $\begin{array}{l}\text { i. The drivers stop at } \\
\text { rest areas for the } \\
\text { customers to pray }\end{array}$ & 4.80 & 5.85 & 0.81 \\
\hline & & mean & 4.80 & 5.85 & 0.82 \\
\hline
\end{tabular}

TABLE 2. Cont

\begin{tabular}{|c|c|c|c|c|c|}
\hline \multirow[t]{10}{*}{2} & \multirow[t]{10}{*}{ Tangibles } & $\begin{array}{l}\text { a. the transport } \\
\text { equipment used in } \\
\text { the bus is updated }\end{array}$ & 4.75 & 5.76 & 0.83 \\
\hline & & $\begin{array}{l}\text { b. the bus had } \\
\text { attractive visuals }\end{array}$ & 4.78 & 5.41 & 0.88 \\
\hline & & $\begin{array}{l}\text { c. employees dress } \\
\text { neatly }\end{array}$ & 4.77 & 5.52 & 0.86 \\
\hline & & $\begin{array}{l}\text { d. the counter workers } \\
\text { dress neatly }\end{array}$ & 4.63 & 5.42 & 0.8 \\
\hline & & $\begin{array}{l}\text { e. bus in a good } \\
\text { condition }\end{array}$ & 4.98 & 6.09 & 0.82 \\
\hline & & $\begin{array}{l}\text { f. the terminal } \\
\text { facilities is good }\end{array}$ & 4.68 & 5.81 & 0.81 \\
\hline & & $\begin{array}{l}\text { g. materials used by } \\
\text { the bus is good }\end{array}$ & 4.38 & 5.41 & 0.80 \\
\hline & & $\begin{array}{l}\text { h. the engines are in } \\
\text { good condition }\end{array}$ & 4.81 & 6.01 & 0.80 \\
\hline & & $\begin{array}{l}\text { i. bus or vehicles are } \\
\text { new (less than } 5 \\
\text { years) }\end{array}$ & 4.44 & 5.73 & 0.78 \\
\hline & & mean & 4.68 & 5.68 & 0.83 \\
\hline \multirow[t]{10}{*}{3.} & \multirow[t]{10}{*}{ Assurance } & $\begin{array}{l}\text { a. Can give confident } \\
\text { to the customers }\end{array}$ & 4.68 & 5.81 & 0.80 \\
\hline & & $\begin{array}{l}\text { b. Feeling safe when } \\
\text { using the bus }\end{array}$ & 4.83 & 5.99 & 0.81 \\
\hline & & $\begin{array}{l}\text { c. The workers are } \\
\text { gracious in handling } \\
\text { the customers }\end{array}$ & 4.42 & 5.80 & 0.76 \\
\hline & & $\begin{array}{ll}\text { d. Workers } & \text { knew } \\
\text { answering } \\
\text { customers }\end{array}$ & 4.47 & 5.67 & 0.79 \\
\hline & & $\begin{array}{l}\text { e. The drivers are } \\
\text { prudent }\end{array}$ & 4.65 & 5.93 & 0.78 \\
\hline & & $\begin{array}{l}\text { f. Drivers follow the } \\
\text { speed limit }\end{array}$ & 4.32 & 5.63 & 0.77 \\
\hline & & $\begin{array}{l}\text { g. Workers answer } \\
\text { easily understood }\end{array}$ & 4.81 & 5.77 & 0.83 \\
\hline & & $\begin{array}{l}\text { h. Workers } \\
\text { customer } \\
\text { complaints }\end{array}$ & 4.28 & 5.52 & 0.77 \\
\hline & & $\begin{array}{l}\text { i. Customers can } \\
\text { make complaints if } \\
\text { not satisfied }\end{array}$ & 4.69 & 5.86 & 0.80 \\
\hline & & mean & 4.57 & 5.77 & 0.79 \\
\hline \multirow[t]{6}{*}{4.} & \multirow[t]{6}{*}{$\begin{array}{l}\text { Responsiv } \\
\text { eness }\end{array}$} & $\begin{array}{l}\text { a. Customers being } \\
\text { informed when the } \\
\text { services being } \\
\text { conducted }\end{array}$ & 4.54 & 5.74 & 0.79 \\
\hline & & $\begin{array}{l}\text { b. Entertain the } \\
\text { customers with } \\
\text { prompt response }\end{array}$ & 4.19 & 5.49 & 0.76 \\
\hline & & $\begin{array}{lr}\text { c. The } & \text { service } \\
\text { providers } & \text { always } \\
\text { ready to help } \\
\text { passengers }\end{array}$ & 4.57 & 5.79 & 0.79 \\
\hline & & $\begin{array}{l}\text { d. Passengers demand } \\
\text { is being entertained } \\
\text { within the } \\
\text { prescribed time }\end{array}$ & 4.28 & 5.61 & 0.77 \\
\hline & & $\begin{array}{l}\text { e. Have flexible } \\
\text { schedule }\end{array}$ & 4.36 & 5.64 & 0.77 \\
\hline & & $\begin{array}{lr}\text { f. Workers } & \text { always } \\
\text { meeting } & \text { the } \\
\text { customer's } & \\
\text { demand } & \\
\end{array}$ & 4.18 & 5.64 & 0.75 \\
\hline
\end{tabular}


TABLE 2. Cont

\begin{tabular}{|c|c|c|c|c|c|}
\hline & & $\begin{array}{l}\text { g. Passengers being } \\
\text { treated equally and } \\
\text { with fairness }\end{array}$ & 4.38 & 5.62 & 0.78 \\
\hline & & $\begin{array}{lr}\text { h. Workers } & \text { are } \\
\text { efficient } & \text { in } \\
\text { managing } & \\
\text { customers' needs } & \end{array}$ & 4.37 & 5.56 & 0.79 \\
\hline & & $\begin{array}{l}\text { i. Customized the } \\
\text { passenger need }\end{array}$ & 4.25 & 5.34 & 0.80 \\
\hline & & mean & 4.35 & 5.59 & 0.78 \\
\hline 5. & Empathy & $\begin{array}{l}\text { a. operations hour is } \\
\text { suitable }\end{array}$ & 4.58 & 5.69 & 0.80 \\
\hline & & $\begin{array}{l}\text { b. workers are given } \\
\text { full consideration to } \\
\text { the problems }\end{array}$ & 4.28 & 5.54 & 0.77 \\
\hline & & $\begin{array}{l}\text { c. workers prioritize } \\
\text { the customers }\end{array}$ & 4.39 & 5.57 & 0.79 \\
\hline & & $\begin{array}{l}\text { d. workers can } \\
\text { understand } \\
\text { customers }\end{array}$ & 4.26 & 5.53 & 0.77 \\
\hline & & $\begin{array}{l}\text { e. } \begin{array}{l}\text { workers } \\
\text { considerate }\end{array} \\
\text { are }\end{array}$ & 4.20 & 5.51 & 0.76 \\
\hline & & $\begin{array}{ll}\text { f. workers } & \text { give } \\
\text { sympathies }\end{array}$ & 4.16 & 5.43 & 0.77 \\
\hline & & $\begin{array}{l}\text { g. the company gave } \\
\text { full help to } \\
\text { customers }\end{array}$ & 4.34 & 5.54 & 0.78 \\
\hline & & $\begin{array}{l}\text { h. workers have good } \\
\text { hospitality }\end{array}$ & 4.41 & 5.62 & 0.78 \\
\hline & & $\begin{array}{l}\text { i. workers respect the } \\
\text { customers }\end{array}$ & 4.63 & 5.72 & 0.81 \\
\hline & & mean & 4.35 & 5.57 & 0.78 \\
\hline & $\begin{array}{l}\text { customer } \\
\text { satisfaction }\end{array}$ & mean & 4.04 & 5.66 & 0.71 \\
\hline
\end{tabular}

\section{Gap Analysis}

A gap analysis was conducted to determine the elements in service quality dimensions that needed to be considered by the transportation providers. The satisfaction gap was evidence in all elements in service quality. The biggest gap was the responsive elements (1.25), followed by empathy elements (1.22), and the smallest gap was the tangible elements (1.00). For service quality dimensions, the most dimensions that needed to be considered were: i) reliability elements (buses were always delayed with value gap -1.47 , ii) responsiveness elements (workers were not customer friendly with value gap of -1.460; and lastly iii) tangible elements (buses were appealing with value gap of 0.63 ). There was a big gap between the overall satisfaction and overall importance of service quality at value -1.62 . This showed that there had been difference in perceptions between what was expected and what was provided by the customers (see Table 3). Thus, failure to match these expectations and reality could lead to customer dissatisfaction.
TABLE 3: QUALITY ANALYSIS OF EACH ELEMENTS AND SERVICE DIMENSION

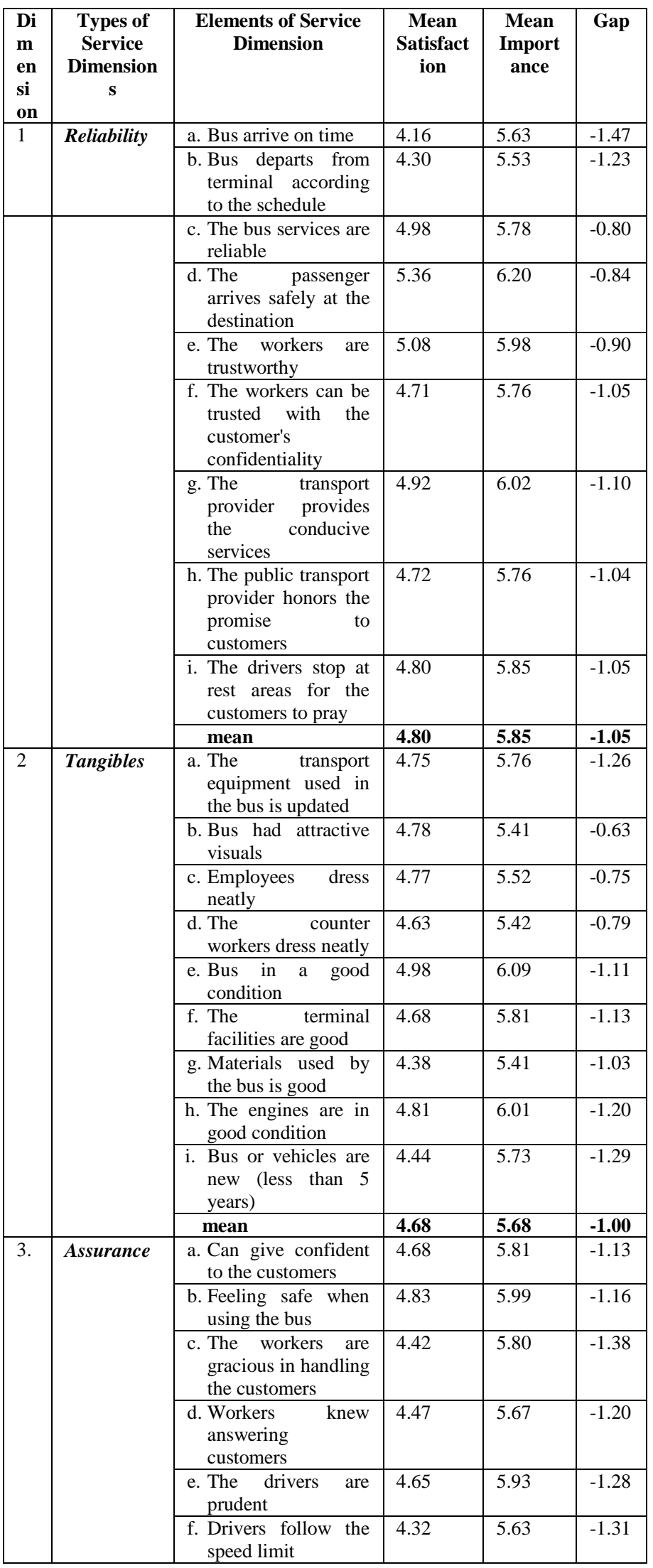


TABLE 3. Cont

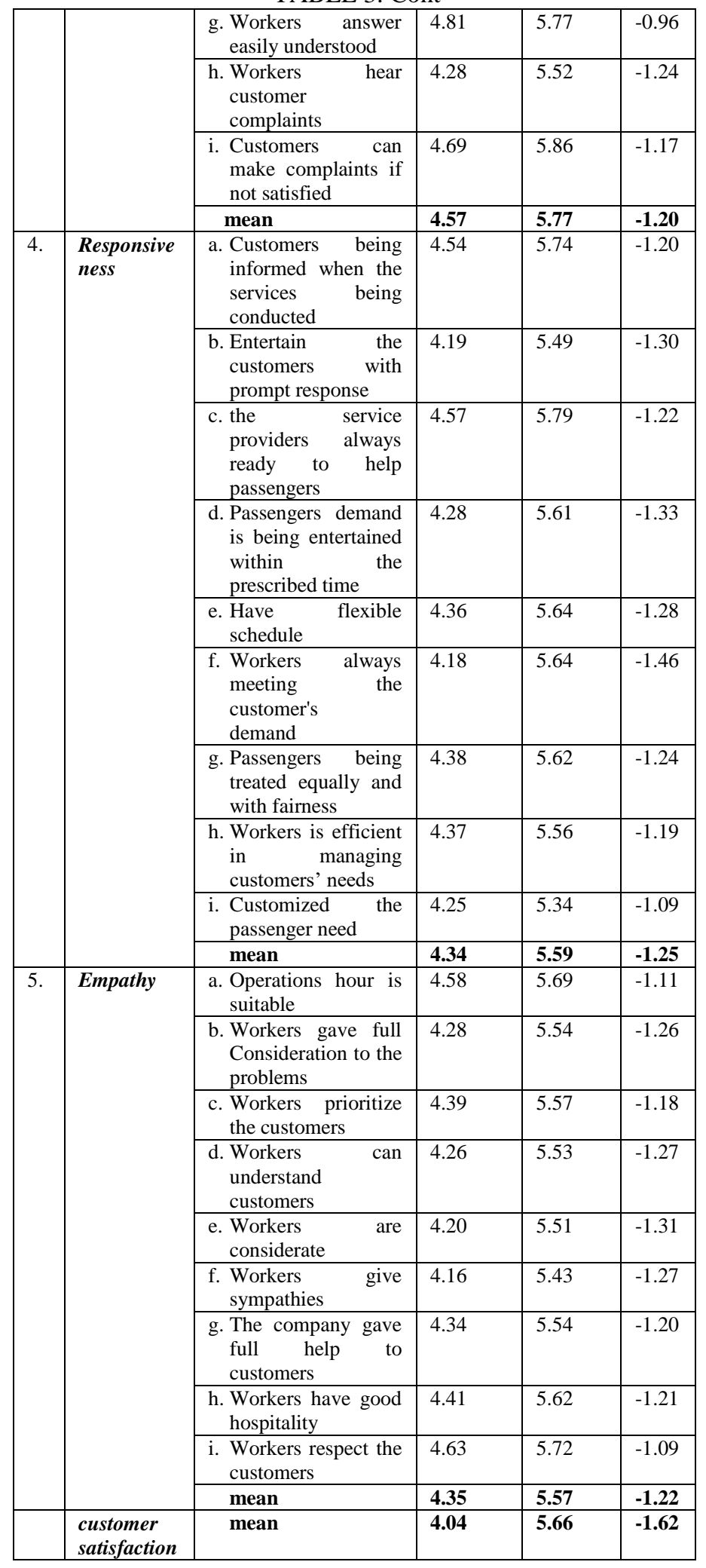

\section{RECOMMENDATION AND DISCUSSION}

Based on the research findings, public transportation operators and local government can improve the quality of public transportation service because many complaints had been made with little response to them. Complaints such as buses did not arrive on time or according to schedule had made the customers feel inconvenient because they need to reschedule their planned trip and this at times would cost them more money. Apart from that, complaints about not having prompt responses and inefficient workers also had been lodged to Public Complaint Bureau [3] [5] [1]. There are many researches that had highlighted the influence of service quality to customer satisfaction [19] [25] [26] [23] [24] [9] [2] [6] [20] [21] [22] [7] [8].

This research findings was also supported by the previous findings that state, workers played important roles in improving the customer satisfaction especially on dimension such as responsiveness and empathy [2] [6] [7] [8] [9] [19] [20] [21] [22] [23] [25] [26]. Workers that were reliable, emphatic, gracious, courteous, detailed, co-operative and always ready to hear customers woes would create the positive perception to the customers or vice versa.

Since Islamic management perspectives centered on the values, values such as fairness or equality, trustworthy, upheld promises, patience, and enable customers to perform their Muslims' obligations can contribute to customer satisfaction [2] [6] [19] [21] [22]. According to Chen et al. (2004), in [9] suggested technology such COSE, (Customer Service Excellent) was one of the systems that could improve the customer orientation services in public sector. This system suggested five approaches that consisted of continuous improvement to quality in public services; identifying customers, survey questionnaires of customers' needs, designing the service system, delivery service and restoration of services to improve the quality of public sector. This proposal could be implemented in public transportation services to improve their services since most of the complaints were on workers' empathies. Hence, if workers' empathies could be increased thus, customers' satisfaction would be augmented. Furthermore, in this research, the empathy and responsiveness elements had the most dissatisfaction from the customers (mean=4.35). This study proposed that empathy and responsiveness elements could be further improved through the concentration of the Islamic management.

\section{LIMITATIONS OF THIS RESEARCH}

This research attempted to find the service quality dimensions that could influence customer satisfaction from the Islamic perspective in public transportation services. However, there are limitations to the study. Firstly, the sample size is only about 160 samples. Thus, generalization to the bigger population was restricted. Secondly, data analysis had not been done rigorously such as the use of Smart PLS or multivariate analysis

\section{RECOMMENDATION FOR FUTURE RESEARCH}

This study had opened new notions for future research. Firstly, future research should do comparison study between public transportations services in rural and urban cities. Secondly, the sample size should be increased to minimal numbers of 1:10 observations of respondents. Thirdly, analysis method should be more rigorous since customer satisfaction 
and SERVQUAL had been extensively examined, qualitative or triangulation methods should be administered to under the issues profoundly.

\section{VIII.CONCLUSION}

As a conclusion, customer satisfaction is important to ensure the viability of an organization. Thus, service quality is significant to have customers supporting the organization. Organization needs to have an image whereby they can be considered as trustworthy and accountable to their customers. One of the ways to have the image is rebranded the organization through instilling the Islamic values in the business service quality and hence public transportation sector. This would warrant high customer satisfaction for the organization.

\section{References}

[1] Izwaashura Sadali, "Penggunaan Pengangkutan Awam di KL Disasarkan Meningkat $60 \%$ menjelang 2020", $4^{\text {th }}$ May 2016", Web Automotif Paultan.org, Web, $1^{\text {st }}$ September 2017

[2] Siti Haryati Shaikh Ali, Noor Malinjasari Binti Ali dan Norudin Mansur, "Quality of Bus Service in Terengganu: A Preliminary Analysis," In Proceedings of the $1^{\text {st }}$ Terengganu International Business and Economic Conference, Primula Beach Resorts and Hotel, Kuala Terengganu, Malaysia, 2008.

[3] Malaysia's Prime Minister Dept, Public Complaint Bureau, "Monitoring of Complaint Received by Ministries/Complaint Received Directly by Ministries in 2010", 2011, Annual Report 2010, Web, $1^{\text {st }}$ September 2010.

[4] Kerajaan Negeri Terengganu, Jabatan Perancangan Bandar dan Desa Negeri Terengganu, "Corak Pembanagunan Fizikan dan Pemuliharaan Sekitar Negeri - Perhubungan dan Pengangkutan”, 2006, Rancangan Pembangunan Negeri Terengganu 2006-2020, Web, $1^{\text {st }}$ September 2017.

[5] Farah Syazwani Ali, "Tingkat Sistem Pengangkutan Awam", post $1^{\text {st }}$ Ocotber 2014, Web, $1^{\text {st }}$ September 2017.

[6] Munusamy J, Chelliah S, Hor WM, "Service quality delivery and its impact on customer satisfaction in the banking sector in Malaysia," International Journal of Innovation, Management and Technology, Vol. 1, No. 4, pp. 398-404, 2010.

[7] Selvanathan M, Selladurai S, S.Gill, S, Kunaserakran. Pei, J.T, "The customer satisfaction status towards core governmental service in Malaysia," International Journal of Business and Management, Vol. 11, No. 5, pp. 211-218, 2016

[8] Radhita Hapsari, Michael D. Clemes, David Dean, "The impact of service quality, customer engagement and selected marketing constructs on airline passenger loyalty," International Journal of Quality and Service Sciences, Vol. 9, Issue 1, pp. 21-40, 2017.

[9] Arawati, A., Baker, S. \& Kandampully, J, "An exploratory study of service quality in the Malaysian public service sector," International Journal of Quality \& Reliability Management, Vol 24, Issue 2, pp. 177 190, 2007.

[10] Ancarani, A. \& Capaldo G, "Management of standardized public services: A comprehensive approach to quality assessment," Managing Service Quality, Vol 11, Issue 5, pp. 331, 2001

[11] Parasuraman, A., Zeithmal, A. V \& Berry, L.L, "SERVQUAL: multiple-item scale for measuring consumer perceptions of service quality," Journal of Retailing, Vol 64, Issue 1, pp. 12-40, 1988.

[12] Al-Quranul Kareem

[13] Al-hadith

[14] Olurunniwo, F., Hsu, Mk and Udo, G.J, "Service quality, customer satisfaction and behavioral intentions in the service factory," Journal of Service Marketing, Vol 20, No 1, pp. 59-72, 2006.
[15] Andaleeb, S.S and Conway, C, "Customer satisfaction in the restaurant industry: an examination of the transaction specific model," The Journal of Service Marketing, Vol. 20, No. 1, pp. 3-11, 2006.

[16] Gilbert, G.R. and Veloutsou, C, "A cross-industry comparison of customer satisfaction," The Journal of Service Marketing, Vol. 20, No. 5, pp. 298-308, 2006

[17] A.G.A. Ilhaamie, "Service quality in Malaysian public service: some findings," International Journal of Trade, Economics and Finance, Vol 1, No. 1, pp. 40-45, 2010.

[18] Al-Tamimi, H.A and Al-Amiri. A, "Analyzing service quality in the UAE Islamic Banks,” Journal of Financial Service Marketing, Vol. 8, No. 2, pp. 119-132, 2003.

[19] Brady, M.K. \& Cronin Jr., J.J, "Some new thoughts on conceptualizing perceived service quality: a hierarchical approach," Journal of Marketing, Vol 65, No.3, pp. 34-49, 2001.

[20] Rohana Kamaruddin, Ismah Osman dan Che Anizaliana Che Pei, "Public transport services in Kelang Valley: Customer expectations and its relationship using SEM," Procedia-Social and Behavioral Sciences, Vol. 36, pp. 431-438, 2012

[21] Na'asah Nasrudin Katiman Rostam dan Rosniza Aznie Che Rose, ISSN 2180-2491 "Persepsi penduduk Shah Alam terhadap dasar pengangkutan dan kesediaan mengguna pengangkutan mampan,' GEOGRAFIA OnlineTM Malaysian Journal of Society and Space, Vol. 10 (2), pp. 133 - 142, 2014.

[22] Harifah Mohd Noor, Na'asah Nasrudin and Jerry Foo, "Determinants of customer satisfaction of service Quality:City bus service in Kota Kinabalu, Malaysia,” Procedia - Social and Behavioral Sciences, Vol. 153 , pp. $595-605,2014$

[23] Sierra, J., \& McQuitty, S, "Service providers and customers: Social exchange theory and service loyalty," Journal of Service Marketing, Vol. 19, No. 6, pp. 392 - 400, 2005.

[24] Chica-Olmo.J, Gachs-Sanchez Hector, Lizaeeaga.C, "Route effect on the perception of public transport service quality. transport policy", 2017, web. $1^{\text {st }}$ Sept, 2017

[25] Singh, J, "Performance productivity and quality of frontline employees in service organization," Journal of Marketing, Vol. 64(2), pp. 15 - 34 2000.

[26] Van Dolen, W., Lemmink, J., Mattsson, J., \& Rhoen, I, “Affective customer responses in service encounters: The emotional content in narratives of critical incidents," Journal of Economic Psychology, Vol. 22, No.3, pp. 359 - 376,2001.

[27] Wan Rosmanira Ismail, Zalina Mohd Ali, Nur Riza Mohd Suradi dan Rofizah Mohammad, "Pengukuran Kepuasan Pelanggan Terhdap Kualiti Perkhidmatan Majlis Perbandaran: Kajian Kes Majlis Perbandaran Ampang Jaya," Journals of Quality Measurement and Analysis, Vol. 3(1), pp. 131-147, 2007. 